\title{
Review of 'Educated tastes: food, drink, and connoisseur culture' edited by Jeremy Strong
}

\author{
Mark C Pachucki
}

\author{
Book details \\ Strong, J (Ed.) \\ Educated Tastes: Food, Drink, and Connoisseur Culture. \\ Lincoln: University of Nebraska Press; 2011. \\ 320 pages, ISBN 978-080-321-935-9 \\ Keywords: Taste preferences and knowledge, Connoisseurship, Gastronomy
}

Educated Tastes: Food, Drink, and Connoisseur Culture is a new collection of essays organised with the goal of explicating social dimensions of taste, frequently obscured in physiological studies of food consumption. As editor Jeremy Strong notes in the preface, a primary theme is the connection between knowledge and taste. A majority of the chapters speak to the idea that how we engage the world informs how we eat and how we interpret our experiences with food. Partially because this volume is aimed at a humanistic readership rather than a specialised biomedical audience, it encourages us to pursue clarity by virtue of the myriad vagaries and imprecisions with how we discuss flavour in the context of food consumption.

Readers of Flavour are likely to be most interested in pieces that relate to our physiological experience of taste. Despite Lisa Harper's wishes that her child have adventurous tastes, her frustration when he transforms into a picky eater exposes the contemporary limits of knowledge about taste development in the womb and about taste avoidance in early life. John Ducker's experiences teaching wine appreciation relate how his students learn to distinguish subtleties in flavour. Haden's concluding chapter on connoisseurship rewards a close read for its focus on gastronomic appreciation, gustatory taste, and the modern tendency towards an omnivorous palate. Investigating how morality can shape food decisions, Strong uses the trope of 'deadly sins' as a device to explore how types of animal cruelty are interwoven with our desire to consume,

Correspondence: pachuckim@chc.ucsf.edu

Robert Wood Johnson Foundation Health \& Society Scholars Program, University of California, San Francisco, 3333 California Street, Suite 465, Campus Box 0844, San Francisco, CA 94143-0844, USA and connects these forms of cruelty with the example of eating ortolan. Another idea running through the volume is the key role that geography plays in our taste experience. In a study of terroir, cuisine, and local beer in Flemish Brabant, Tim Waterman generates a theory of 'accrued taste' (differentiated from acquired tastes) while arguing for peripheral urban areas as promising sites to reclaim local food heritage. Chapters on refinement in Soviet cooking and the roles of food in Italian nationalistic sentiment complement this focus.

Taken as a whole, the idea explored in this volume that the social world interacts with and informs the body's needs is not a new one. Yet this collection speaks to a growing acknowledgement across the sciences that to disregard the role of social context in examining flavour and how we consume is to impoverish our understanding of how taste emerges and changes.

\section{Competing interests}

The author declares that he has no competing interests.

Authors' contributions

MCP drafted this review.

\section{Authors' information}

MCP is a sociologist whose research focuses on how networks of social relations shape our taste preferences and our health.

\section{Acknowledgements}

The author gratefully acknowledges the support of the Robert Wood Johnson Foundation for fellowship support.

Received: 4 July 2012 Accepted: 17 July 2012 Published: 3 September 2012

\section{doi:10.1186/2044-7248-1-16}

Cite this article as: Pachucki: Review of 'Educated tastes: food, drink, and connoisseur culture' edited by Jeremy Strong. Flavour 2012 1:16.

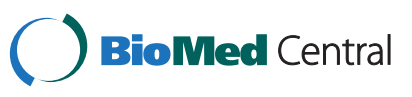

(c) 2012 Pachucki; licensee BioMed Central Ltd. This is an Open Access article distributed under the terms of the Creative Commons Attribution License (http://creativecommons.org/licenses/by/2.0), which permits unrestricted use, distribution, and reproduction in any medium, provided the original work is properly cited. 